\title{
CD248 wt Allele
}

National Cancer Institute

\section{Source}

National Cancer Institute. CD248 wt Allele. NCI Thesaurus. Code C78158.

Human CD248 wild-type allele is located in the vicinity of $11 \mathrm{q} 13$ and is approximately $3 \mathrm{~kb}$ in length. This allele, which encodes endosialin protein, may be involved in angiogenesis. 